\section{It's all about relationships}

BY JAMIE JONES MILLER ('99), immediate past president, JMU Alumni Association

When I speak with JMU students, alumni and parents the conversation always seems to come back to the feeling that JMU is more than just a place. Parents at Spring Commencement told me that JMU was truly a home away from home for their sons and daughters and members of the Class of 2014 were already making plans to come back "home" to JMU this fall. Bluestone Reunion attendees, some of whom have not been on campus since their graduation 50 years ago, often reflect on how welcoming and friendly people on campus are.

I know that alumni who gathered on campus for the annual Madison Alumni Conference in June were eager to visit their old stomping grounds, but they were even more excited to see new facilities like University Park, JMU's "backyard," and the Student Success Center which has moved into the old Rockingham Memorial Hospital complex. Many conference attendees told me that despite of all the growth and physical changes to campus, JMU still feels like home to them.

Alumni representing alumni chapters, the Duke Club, Admissions Recruitment Volunteers, the Alumni Association Board of Directors and students representing the Student Alumni Association met at the Madison Alumni Conference to share ideas and plan for the future. While there was a lot of business to get done, the weekend felt more like a family reunion! Purple and gold-clad alumni and student leaders caught up with old friends, took selfies around campus and reminisced about the past during a lunch featuring JMU dining favorites like buffalo mash and chocolate peanut butter ice cream. These dedicated volunteers are working every day to help connect and engage alumni in support of our alma mater, and they have partnered with the university in numerous ways to bring JMU to you. Alumni and Duke Club chapter events, the Coaches Caravan, college fairs, first-year send offs, and events with President Jonathan R. Alger and senior administrators are happening across the United States and even abroad. what lies ahead. is still at JMU.

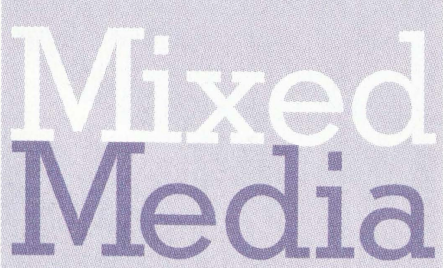

B O O K S, MU S I C E F I L M

\section{Myself and Some Other Being: Wordsworth and the Life Writing}

BY DANIEL ROBINSON ('92) UNIVERSITY OF IOWA

PRESS, 2014

ISBN: 978-1-60938-232-2

English major Daniel Robinson ('92) is a professor of English at Widener University and the author of The Poetry of Mary Robinson: Form and Fame and William Wordsworth's Poetry. Robinson's book is the story of Wordsworth becoming Wordsworth by writing the fragments and drafts of what would eventually become The Prelude, an autobiographical epic poem addressed to Coleridge that he hid from the public and was only published after his death in 1850. In focusing on this young, ambitious, yet insecure Wordsworth struggling to find his place among other writers, Robinson demonstrates how The Prelude may serve as a provocative, instructive and inspirational rumination on

the writing

of one's own life. Concen-

trating on

the process

of Words-

worth's

endless

revisions, the real literary business of creativity,

Robinson puts Wordsworth forward as a model and

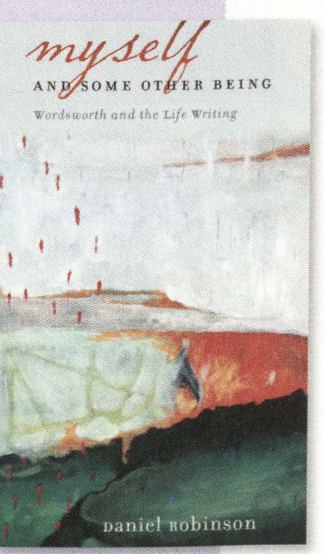
ience, and the relationships I have built alon the way are priceless. Remember that we are Dukes from Day One, but Alumni for Life. Informed, involved and invested alumni will lead JMU into the future and I can't wait to see

Home is where the heart is, and I think mine

m

$\rightarrow$ FOLLOW Jamie Jones Miller ('99) @JMUJamie 